\title{
Profesor Michał Seweryński Pięćdziesiąt lat pracy z pasją
}

ięćdziesiąt lat pracy można przeżyć nieciekawie i niewidocznie. Pro-
fesor Seweryński przeżył je z pasja, wola działania i zmieniania rzeczy na lepsze, zajmując od początku widoczne, a z czasem bardzo widoczne miejsce w dziedzinach, którymi się zajmował. Nieraz powtarzał, że lepsze jest wrogiem dobrego. I tej dewizy trzyma się do dziś.

Początkiem jego drogi naukowej były studia doktoranckie w Uniwersytecie Łódzkim, rozpoczęte w 1965 r. pod kierunkiem profesora Wacława Szuberta, po krótkim epizodzie pracy w prokuraturze. Już w czasie studiów prof. Szubert zafascynował go swoimi wykładami z prawa pracy i polityki społecznej. Wybitne cechy umysłu i charakteru Wacława Szuberta sprawiły, że stał się on dla Profesora nie tylko mistrzem naukowym, lecz także przewodnikiem w kluczowych momentach życia. Pracę doktorską w dziedzinie prawa pracy obronił Michał Seweryński w roku 1969. Habilitował się w roku 1977, również w tej dziedzinie. Tytuł profesora uzyskał w roku 1987.

Od pierwszego dnia pracy naukowej Profesor Seweryński jest związany z Uniwersytetem Łódzkim, gdzie przeszedł kolejne szczeble kariery naukowej oraz pełnił coraz wyższe funkcje akademickie: prodziekana Wydziału Prawa i Administracji (1981-1984), dziekana tego Wydziału (19841987), a następnie prorektora (1987-1990) i dwukrotnie rektora (19901996). Na Wydziale Prawa i Administracji Uniwersytetu Łódzkiego Profesor Seweryński utworzył w 1993 r. Zakład Zbiorowego Prawa Pracy, podejmując z zespołem współpracowników badania i dydaktykę $\mathrm{w}$ tej

* Dr hab., prof. nadzw. Uniwersytetu Łódzkiego, kierownik Zakładu Europejskiego i Zbiorowego Prawa Pracy, sędzia Sądu Najwyższego. 
kształtującej się wówczas na nowo dziedzinie prawa pracy. Następnie, w 1994 r., dostrzegając, w perspektywie akcesji Polski do Wspólnoty Europejskiej, konieczność kształcenia kadr i prowadzenia badań prawa ówczesnej Wspólnoty Europejskiej, zorganizował Katedrę Prawa Europejskiego, jako Chaire Jean Monet. W jej skład weszły trzy zakłady: Europejskiego Prawa Gospodarczego, Europejskiego Prawa Socjalnego i Zbiorowych Stosunków Pracy oraz Europejskiego Prawa Instytucjonalnego. Taka struktura Katedry stworzyła rozległy horyzont badawczy, a comiesięczne seminaria naukowe, prowadzone z żelazną regularnością przez Profesora, dawały licznym ich uczestnikom - pracownikom i doktorantom - szerokie możliwości poznawania i dyskutowania zagadnień różnych dziedzin prawa europejskiego ${ }^{1}$. Katedra stała się $\mathrm{w}$ następnych latach prężnym ośrodkiem naukowo-dydaktycznym w tej dziedzinie prawa, kształcącym kadry naukowe, organizującym konferencje i wydającym czasopismo naukowe „Studia Prawno-Europejskie”, którego Profesor Seweryński był redaktorem naczelnym. Pod jego kierunkiem i opieką naukową pięciu pracowników uzyskało stopień doktora. Trzy z tych osób uzyskały stopień doktora habilitowanego i stanowiska profesorów, jedna tytuł profesora. W tym okresie dwoje pracowników Katedry objęło stanowiska sędziów (w Sądzie do Spraw Służby Publicznej Unii Europejskiej i w Sądzie Najwyższym RP), jeden został członkiem Rady Legislacyjnej, dwie osoby pełniły funkcje rządowe (w Ministerstwie Pracy i w Ministerstwie Spraw Zagranicznych). W 2008 r., w związku z rozwojem kadrowym i naukowym, Katedra Prawa Europejskiego podzieliła się na dwie jednostki, a Profesor Seweryński kierował do czasu przejścia na emeryturę Katedrą Europejskiego Prawa Gospodarczego i Zbiorowego Prawa Pracy. Przez cały czas pracy w Uniwersytecie Łódzkim, łącznie z latami, w których pełnił funkcję ministra w Rządzie RP, prowadził zajęcia dydaktyczne. Obecnie kontynuuje pracę naukowo-dydaktyczną w Uniwersytecie Łódzkim jako profesor zwyczajny w samodzielnym Zakładzie Europejskiego i Zbiorowego Prawa Pracy. Wielokrotnie wykonywał też obowiązki recenzenta w przewodach doktorskich, habilitacyjnych i profesorskich.

W latach 1996-2005 Michał Seweryński był także profesorem w Salezjańskiej Wyższej Szkole Ekonomii i Zarządzania, współpracującej z Uniwersytetem Łódzkim. W latach 1997-2013 był również dyrektorem Centrum Społecznego Dialogu Pracy w Akademii Ekonomicznej w Katowicach - jednostce naukowej i dydaktycznej zajmującej się badaniem i wspieraniem społecznego dialogu pracy.

${ }^{1}$ O tym okresie pracy Profesora zob. też: M. Królikowska-Olczak, Profesor Michał Seweryński - twórca Katedry Prawa Europejskiego w Uniwersytecie Łódzkim, [w:] Profesor Michat Seweryński, [w:] Sylwetki Łódzkich Uczonych, red. Z. Hajn, Łódzkie Towarzystwo Naukowe, Łódź 2009, s. 19. 
Profesor Seweryński aktywnie uczestniczy w pracy polskich towarzystw naukowych: Łódzkiego Towarzystwa Naukowego (od 1984 r.), Komitetu Nauk Prawnych PAN (członek w latach 2002-2005) i Polskiego Stowarzyszenia Prawa Pracy i Zabezpieczenia Społecznego, w którym działa od 1980 r. i któremu od 1999 do 2008 przewodniczył.

Od lat Profesor prowadzi ożywioną działalność naukowo-dydaktyczną poza granicami Polski, w czym pomaga mu biegła znajomość języków francuskiego, angielskiego i rosyjskiego oraz operacyjna znajomość kilku innych. Kontakty z nauką zagraniczną rozpoczął Michał Seweryński już w latach 1971-1972, uczestnicząc w letnich kursach porównawczego prawa pracy $w$ Ecole Internationale de Droit du Travail et de la Sécurité Sociale w Trieście. Wprawdzie wykłady i egzaminy odbywały się tam po francusku, ale duże wrażenie zrobiły na nim wówczas włoski język i same Włochy, z którymi od tej pory nie traci kontaktu. W roku 1977 odbył sześciomiesięczny staż na Uniwersytecie Paris I - Sorbonne. Ten staż był dla niego okazją do rozwinięcia zainteresowań naukowych oraz do nawiązania cennych kontaktów z francuskim środowiskiem naukowym. Później pracował w kilku innych uniwersytetach francuskich. Obecnie jego pozycji naukowej za granicą dowodzi to, że wielokrotnie był referentem generalnym na europejskich i światowych kongresach prawa pracy i zabezpieczenia społecznego oraz prawa porównawczego. Prowadził także pracę dydaktyczną jako visiting professor na uniwersytetach w Paryżu, Bordeaux, Nantes, Saint-Etienne, Quebec, Barcelonie, Genewie i Tokio oraz jako stały wykładowca Międzynarodowego Seminarium Prawa Pracy i Zabezpieczenia Społecznego w Szegedzie, a następnie w Bordeaux. Działa w zagranicznych towarzystwach naukowych: Société de Législation Comparée, z siedzibą w Paryżu (od roku 1979), Rossijskaja Asocjacja Trudovogo Prava, z siedzibą w Moskwie (od roku 1993), Academia Europaea z siedzibą w Londynie (od roku 1995), Academie International de Droit Comparé, z siedzibą w Paryżu (od roku 2000), Association Henri Capitant, z siedzibą w Paryżu (od roku 2004 przewodniczący Sekcji Polskiej tego Stowarzyszenia), Société Historique et Littéraire Polonaise w Paryżu (od 2008 roku, współprzewodniczący Rady Naukowej razem z panią Hélène Carrère d'Encausse - Secrétaire perpétuelle de 1'Académie Française), International Society for Labour and Social Security Law, z siedzibą w Genewie (od roku 1980). Tej ostatniej organizacji, będącej najważniejszym międzynarodowym stowarzyszeniem prawa pracy i zabezpieczenia społecznego, Profesor Seweryński był w latach 2000-2003 wiceprezydentem, a w latach 2009-2012 prezydentem².

${ }^{2}$ Zob. też: L. Florek, Dorobek zagraniczny i międzynarodowy prof. zw. dr. hab. Michała Seweryńskiego, [w:] Profesor Michat Seweryński, [w:] Sylwetki Łódzkich Uczonych..., s. 13-14. 
Najważniejsze miejsce w pracy Profesora Michała Seweryńskiego zajmowała i zajmuje twórczość naukowa w zakresie prawa pracy. Jego dorobek piśmienniczy obejmuje ponad 170 pozycji. Sześćdziesiąt z nich to publikacje w językach obcych (angielskim, francuskim, niemieckim, rosyjskim i hiszpańskim). Publikacje te spaja klamra jasno wyrażanego szacunku dla człowieka i jego pracy oraz sprzeciwu wobec dominacji celów politycznych i ekonomicznych realizowanej kosztem ludzi pracy. Niezależnie od walorów moralnych i naukowych, prace Profesora cechuje bardzo jasna i logiczna konstrukcja, klarowny wywód oraz dbałość o poprawność języka. Jego szczególna wrażliwość na tym punkcie jest znana w środowisku naukowym i wśród studentów.

Twórczość Michała Seweryńskiego jest bogata i różnorodna, dotyczy wielu obszarów prawa pracy. Niektóre wątki badawcze zajmują jednak szczególne miejsce $\mathrm{w}$ jego dorobku. Wiele publikacji poświęcił jednej z podstawowych instytucji indywidualnego prawa pracy - wynagrodzeniu za pracę. Jego monografia tej instytucji (Wynagrodzenie za prace, PWN, Warszawa 1981), do dzisiaj zachowała teoretyczną aktualność i jest nadal czołową pozycją z tego zakresu. Szczególną uwagę Profesora Seweryńskiego przyciągnęło też międzynarodowe prawo pracy. Do tego obszaru należy wydana w 1983 r. książka Konwencje MOP ratyfikowane przez Polskę, z obszernym wstępem wyjaśniającym mechanizmy działania MOP oraz charakter i oddziaływanie konwencji tej organizacji na prawo krajowe, a także ukazującym niezbędne w tym okresie wzorce demokratycznego prawa pracy. Dopełnieniem tego dzieła było wydane w 1988 r. (wspólnie z Ludwikiem Florkiem) Międzynarodowe prawo pracy, pozostające do dziś jedynym podręcznikiem tej dziedziny prawa pracy w Polsce. Z wyczuciem tego co ważne, Profesor zajmuje się od lat osiemdziesiątych ubiegłego stulecia problematyką udziału pracowników w zarządzaniu zakładem pracy i przedsiębiorstwem (będącą obecnie wiodącą częścią zbiorowego prawa pracy Unii Europejskiej), poświęcając tej kwestii liczne publikacje, formułując pojęcia tego działu zbiorowego prawa pracy, biorąc udział $\mathrm{w}$ międzynarodowej debacie na ten temat, propagując w Polsce osiągnięcia zagraniczne i przedstawiając polskie koncepcje za granicą. $\mathrm{O}$ jego pozycji w tym zakresie świadczy dzieło Handbook on Employee Involvement in Europe wydane przez niego w 2005 r. we współredakcji z profesorem Manfredem Weissem. Dużo uwagi Profesor poświęcił także zagadnieniom dialogu społecznego, statusu związków zawodowych i organizacji pracodawców oraz problematyce układów zbiorowych pracy i innych porozumień zbiorowych, jako podstawowych instrumentów tego dialogu. $\mathrm{Z}$ publikacji z tego zakresu zwraca uwagę książka Collective Agreements 
and Individual Contracts of Employment (2003), obejmująca krajowe opracowania tego tematu z wielu państw i wnikliwą, komparatystyczną syntezę jego pióra. Był on także generalnym sprawozdawcą na XVII Kongresie Międzynarodowej Akademii Prawa Porównawczego w temacie „Representation of Employees in Collective Bargaining within the Firm" (publikacja w 2007 r.). Kilka (pięć) publikacji Profesor poświęcił też zagadnieniom rozwiązywania sporów zbiorowych pracy. W jego dorobku znajduje się także klarowna synteza systemu zbiorowego prawa pracy w Polsce, zawarta w monografii Collective Labour Law in Poland (1999).

Profesor zajmował się także licznymi, niewymienionymi wyżej zagadnieniami prawa pracy, w tym, by wspomnieć kwestie, którym poświęcił co najmniej kilka publikacji: przeciwdziałaniem bezrobociu, pracą dzieci i młodocianych, organizacją pracy, podstawowymi prawami socjalnymi, relacją prawa pracy do polityki i gospodarki, elastycznością zatrudnienia i kontraktualizacją stosunków pracy.

Szczególną sferą zainteresowań Profesora, zajmującą wyjątkowe miejsce $\mathrm{w}$ jego naukowych dążeniach od lat osiemdziesiątych, była problematyka reformy, a w późniejszych pracach nowej kodyfikacji indywidualnego i zbiorowego prawa pracy. Kwestii tej poświęcił dziesięć publikacji, nie licząc prac dotyczących propozycji zmian prawa w sprawach szczegółowych. Dążenie do reformy prawa realizował też pełniąc w ciągu wielu lat funkcję członka Rady Legislacyjnej oraz uczestnicząc w komisjach reformy prawa pracy. Ostatniej z nich - Komisji Kodyfikacyjnej Prawa Pracy - przewodniczył od 2003 r., doprowadzając do zakończenia jej prac i przedstawienia rządowi w 2006 r. projektów dwóch kodeksów, reformujących indywidualne i zbiorowe prawo pracy ${ }^{3}$.

Nie sposób w krótkim szkicu przedstawić całego dorobku Profesora Seweryńskiego. Konieczne jest jednak wskazanie jeszcze na serię jego publikacji, prezentującą za granicą przemiany polskiego prawa pracy i dorobek współczesnej polskiej doktryny tego prawa, w tym książki: Polish Labour Law and Collective Labour Relations in the Period of Transformation (1995) i Polish Labour Law from Communism to Democracy (1999). Zwłaszcza ostatnia z nich ukazuje kształtowanie się polskiego prawa pracy od Drugiej Wojny Światowej, jego podstawowe instytucje i perspektywy rozwoju na tle najważniejszych wydarzeń tego okresu. Wspomnieć też należy o serii publikacji, głównie $\mathrm{w}$ języku angielskim i francuskim, prezentujących w Zachodniej Europie problemy prawa pracy i stosunków pracy w Europie Centralnej i Wschodniej w przejściowym okresie od transformacji ustrojowej do przystąpienia do Unii Europejskiej. Towarzyszyły im jednocześnie publikacje ukazujące prawo państw zachodnioeuropejskich w Polsce.

${ }^{3}$ Szerzej na ten temat: G. Goździewicz, Profesor Michał Seweryński Przewodniczacy Komisji Kodyfikacyjnej Prawa Pracy w latach 2003-2006, tekst zamieszczony w niniejszej książce. 
Osobnego omówienia wymaga twórczość Michała Seweryńskiego w sferach wykraczających poza prawo pracy, lecz związanych z jego społecznym i zawodowym zaangażowaniem oraz przekonaniami. Pierwszą są problemy edukacji i szkolnictwa wyższego. Przemyślenia i propozycje z tej dziedziny zawierają w szczególności teksty Profesora dotyczące: systemu płac w nauce (1981), kryteriów akademickości uczelni (1994), etycznych problemów procesu edukacyjnego (2004), polskiej polityki naukowej w kontekście członkostwa w Unii Europejskiej (2006) i strategicznych celów szkolnictwa wyższego (2011). Z kolei z przywiązaniem Profesora do wartości chrześcijańskich łączą się jego wypowiedzi jasno określające znaczenie, jakie im przypisuje, $\mathrm{w}$ tym zwłaszcza publikacje dotyczące tożsamości chrześcijańskiej we współczesnej Europie (2008) i godności pracy człowieka w świetle nauki społecznej Kościoła (2011).

\section{$*$}

Pracy naukowej Profesora towarzyszyła od dawna wysoka aktywność na polu kierowania nauką. Był jednym z inicjatorów powołania Konferencji Rektorów Akademickich Szkół Polskich jako platformy dialogu i przedstawicielstwa w sprawach nauki i szkolnictwa wyższego. Wybranie go do pełnienia funkcji przewodniczącego Konferencji, którą sprawował w latach 1990-1996, potwierdziło jego wybitną pozycję naukową i autorytet, którym się cieszy. Pełniąc tę funkcję Michał Seweryński bronił pozycji i roli uniwersytetów. Przemawiając 4 stycznia 1996 r. na audiencji udzielonej rektorom polskim przez Ojca Świętego Jana Pawła II wskazał na niebezpieczeństwo traktowania uniwersytetów instrumentalnie, jako swoistych przedsiębiorstw dostarczających fachowców i wprzęganych w osiąganie celów politycznych i gospodarczych przez ośrodki władzy. Jako drogę właściwą dla uczelni, zapobiegającą tej groźbie, traktował wierność odwiecznej misji uniwersytetu i sensowi jego istnienia, tj. poszukiwaniu prawdy i krzewieniu jej wśród ludzi.

W roku 2005 prof. Michał Seweryński został powołany w skład Rządu RP, w którym pozostał do 2007 r., pełniąc kolejno funkcje ministra edukacji oraz ministra nauki i szkolnictwa wyższego ${ }^{4}$. Na tych par excellence politycznych stanowiskach kierował swe działania głównie na dostosowanie systemu badań naukowych i szkolnictwa wyższego w Polsce do wymagań wynikających z potrzeb rozwojowych polskiej gospodarki i kultury.

${ }^{4}$ Więcej o tym okresie działalności prof. Seweryńskiego zob. J. Wojtyła, Słowo o Profesorze Michale Seweryńskim, [w:] Profesor Michał Seweryński, [w:] Sylwetki Łódzkich Uczonych..., s. 22. 
Obrazu różnorodnej aktywności Profesora Seweryńskiego dopełnia jego działalność społeczna. W szczególności przez wiele lat (1996-2006) był członkiem Papieskiej Rady ds. Świeckich, do której powołał go papież Jan Paweł II, a w latach 1997-2005 przewodniczył Krajowej Radzie Katolików Świeckich, będącej organem konsultacyjnym Konferencji Episkopatu Polski. W okresie od 1999 do 2005 r. pełnił funkcję Konsula Honorowego Francji w Łodzi. Od roku 2011 Profesor jest senatorem RP, prowadząc aktywną działalność na stanowisku przewodniczącego Senackiej Komisji Praw Człowieka, Praworządności i Petycji.

Za swą działalność Profesor otrzymał Krzyż Kawalerski i Oficerski Orderu Odrodzenia Polski, Chevalier dans l'Ordre national du Mérite (Francja), Les Palmes Académiques (Francja), papieski Krzyż Pro Ecclesia et Pontifice, Odznakę Honorową Miasta Łodzi oraz tytuł doktora honoris causa Uniwersytetu Jean Moulin (Lyon III) w Lyonie.

*

Oparcie w pracy i życiu daje Profesorowi szczęśliwa rodzina - żona Bożenna Maria, syn Piotr, córka Justyna i wnukowie: Filip, Mateusz i Bartłomiej. Rodzina utrzymuje serdeczne i bliskie kontakty, wspierając się w ambitnych zamierzeniach i trudnych chwilach. Profesor żyje nie tylko pracą. Znane jest jego zamiłowanie do muzyki i śpiewu, oddziedziczone, jak twierdzi, po rodzicach, a także do sportu, który uprawia rekreacyjnie do dziś. W sferze między pracą a odpoczynkiem mieści się namiętność Profesora do czytania, tłumacząca jego powszechnie znaną erudycję, oraz do podróży, przez którą wystukując numer jego komórki rozmówca musi wkalkulować możliwość poniesienia dodatkowych opłat połączeń z wieloma odległymi miejscami. 



\section{Professor Michał Seweryński Fifty Years of Work with Passion ${ }^{1}$}

Q Jou can work for fifty years in an uninteresting and invisible way. Professor Seweryński lived those years with passion, the will to act and to change things for the better, becoming, with time, more and more visible in the areas that he was dealing with. He often said the better is the enemy of the good. And he still follows this maxim.

*

Professor Seweryński started his scientific carrier by pursuing a $\mathrm{PhD}$ at the Łódź University under the supervision of Professor Wacław Szubert, after a brief episode at the public prosecutor's office. Already as a student, he was fascinated with labour law and social policy lectures of Professor Szubert. Professor Szubert impressed him with exceptional intellectual capacities and character, thus becoming Professor's academic master, a guide in life and an advisor in key life moments. Michał Seweryński defended his labour law $\mathrm{PhD}$ in 1969, he obtained the postdoctoral degree (habilitacja) in 1977 in the same field and was conferred the title of professor in 1987.

Since the very first day of his academic career, Professor Seweryński has been attached to the University of Łódź where he went through consecutive stages of the scientific career and where he climbed the ladder of academic functions: Deputy Dean of the Law and Administration Faculty (1981-1984), Dean of the same Faculty (1984-1987), later Deputy President of the University (1987-1990) and twice its President (19901996). In 1993 Professor Seweryński created the Collective Labour Law Department at the Faculty of Law and Administration of the University

* Professor at the University of Łódź, Head of the European and Collective Labour Law Department, judge of the Supreme Court).

1 Translated into English by Justyna Seweryńska. 
of Łódź, launching, with a team of collaborators, research and lectures in this new, at the time, field of labour law. Later, in 1994, in the light of future accession of Poland to the European Community, he saw the necessity to educate personnel and to conduct research on the law of the European Community of the time hence he organised the European Law Chair as Chaire Jean Monet. It was composed of three departments: European Economic Law, European Social Law and Collective Labour Relations as well as European Institutional Law. This structure allowed to create a broad research horizon whereas monthly scientific seminars held regularly by Professor gave many of its participants - employees and Ph.D. students - many possibilities to learn and discuss a variety of issues from different fields of European $l_{a w}^{2}$. The Chair quickly became a thriving science and teaching centre in this field of law educating academics, organising conferences and publishing a scientific journal "Studia Prawno-Europejskie" ("Legal-European Studies") with Professor Seweryński as its editor-in-chief. Under his supervision and scientific guidance five members of the staff obtained a Ph.D. Three members of the staff obtained a postdoctoral degree and the position of a professor, and one became a full professor. During that time two employees of the Department were appointed judges (at the European Union Civil 30 Service Tribunal and at the Supreme Court of the Republic of Poland), one became a member of the Legislative Council, two held government positions (at the Ministry of Labour and at the Ministry of Foreign Affairs). In 2008, due to the increase of the staff and to scientific development, the European Law Chair was divided into two units and Professor stayed at the head of the Chair of Economic European Law and Collective Labour Law until his retirement. While working at the University of Łódź, including the years when he held the position of a minister in the Polish Government, he has been teaching. Right now he continues his scientific and teaching work at the University of Łódź as full professor at the independent European and Collective Labour Law Department. Repeatedly he has been the reviewer of doctoral, postdoctoral and professor theses.

In the years 1996-2005 Michał Seweryński was also a professor at the Salesian Higher School of Economics and Management in cooperation with the University of Łódź. Also from 1997 to 2013 he was the Director of the Labour Social Dialogue Centre at the Academy of Economics in Katowice - a scientific and teaching unit researching and supporting labour social dialogue.

2 About this period of the Professor's work see also: M. Królikowska-Olczak, Profesor Michat Seweryński - twórca Katedry Prawa Europejskiego w Uniwersytecie Łódzkim, [in:] Profesor Michał Seweryński, [in:] Sylwetki Łódzkich Uczonych, red. Z. Hajn, Łódzkie Towarzystwo Naukowe, Łódź 2009, p. 19. 
Professor Seweryński has been actively participating in the work of Polish scientific societies: Scientific Society in Łódź (since 1984), Legal Studies Committee of the Polish Academy of Sciences (member from 2002 to 2005) and Polish Society of Labour Law and Social Security, where he had been active since 1980 and that he chaired from 1999 to 2008.

For many years Professor Seweryński has been conducting a lively scientific and teaching activity abroad as he speaks fluent French, English and Russian and he has an operational command of several other languages. His contacts with foreign academics started already in 19711972, when he participated in summer courses of comparative labour law at the Ecole Internationale de Droit du Travail et de la Sécurité Sociale in Trieste. Even though classes and exams were in French, he was impressed with the Italian language and Italy, a country he has remained in touch with ever since. In 1977 he spent six months at the University Paris I - Sorbonne as an intern. This internship gave him the opportunity to develop his scientific interests and to establish precious relations with the French academic milieu. Later on he worked at several other French universities. Right now his academic position abroad is best illustrated by the fact that on many occasions he was a keynote speaker at European and world congresses of labour law and social security as well as of comparative law. He also gave lectures as a visiting professor at universities in Paris, Bordeaux, Nantes, Saint-Etienne, Quebec, Barcelona, Geneva and Tokyo, and as a lecturer at the International Seminar of Labour Law and Social Security in Szeged and later in Bordeaux. Professor Seweryński has been actively participating in foreign science societies: Société de Législation Comparée, based in Paris (since 1979), Rossijskaja Asocjacja Trudovogo Prava, based in Moscow (since 1993), Academia Europaea based in London (since 1995), Académie internationale de droit comparé, based in Paris (since 2000), Association Henri Capitant, based in Paris (2004-2009 President of the Polish Section of this Association), Société Historique et Littéraire Polonaise in Paris (since 2008 co-chair of the Scientific Council together with Mrs Hélène Carrère d'Encausse - Secrétaire perpétuelle de l'Académie Française), International Society for Labour and Social Security Law, based in Geneva (since 1980). Professor Seweryński was Vice President (2000-2003) and President (2009-2012) of the last organisation - the most important international society of labour law and social security ${ }^{3}$.

${ }^{3}$ Zob. też: L. Florek, Dorobek zagraniczny i międzynarodowy prof. zw. dr. hab. Michała Seweryńskiego, [in:] Profesor Michał Seweryński, [in:] Sylwetki Łódzkich Uczonych..., p. 13-14. 
The main part of Professor Michał Seweryński's professional activity has been dedicated to scientific work in the field of labour law. His publications include over 170 works. Sixty works are foreign language publications (English, French, German, Russian and Spanish). These publications have in common a clearly expressed respect for people and their work as well as objections against domination of political and economic goals reached at the expense of the working people. Irrespective of their moral and scientific values, these publications are characterized by a very clear and logical construction, a limpid line of reasoning and attention paid to correct language use. He has been known for being very sensitive about correct Polish language use in the academic milieu and among students.

The achievements of Michał Seweryński are plentiful and diverse in different fields of labour law. Some research themes occupy a special place in his work. Many publications are dedicated to one of the basic institutions of individual labour law - remunerations. His monograph on this institution (Wynagrodzenie za prace /Remuneration/, PWN, Warszawa 1981) has kept its theoretical relevance and has remained until today a key work in this field. Professor Seweryński has been particularly interested in international labour law. In 1983 he published a book Konwencje MOP ratyfikowane przez Polske /ILO Conventions Ratified by Poland/ with a broad introduction explaining the mechanisms of ILO functioning as well as the character and the impact of its conventions on national law, and showing models of democratic labour law necessary in that time. This work was completed by a publication in 1988 (together with Ludwik Florek) entitled International Labour Law, which still remains a highly appreciated source of knowledge about this field of labour law. Knowing what is important, since the 80's of the last century, Michał Seweryński has been dealing with the issue of employee participation in the management of a plant and an enterprise (now a major part of collective labour law of the EU) writing many publications on this subject, formulating notions from this field of collective labour law, participating in the international debate on the subject, promoting foreign achievements in Poland and presenting Polish achievements abroad. His position in this respect is best shown by the work Handbook on Employee Involvement in Europe published in 2005 and coedited with Professor Manfred Weiss. Professor Seweryński dedicated a lot of his attention to the issues of social dialogue, the status of trade unions and employers' organisations as well as of collective agreements as basic instruments of this dialogue. The publications in this field include the book Collective Agreements and Individual Contracts 
of Employment (2003) presenting national studies on this subject in many countries and a shrewd, comparative synthesis written by him. He was also a general rapporteur at the XVII ${ }^{\text {th }}$ Congress of International Academy of Comparative Law on Representation of Employees in Collective Bargaining within the Firm (published in 2007). Several (five) publications are devoted to the subject of collective labour disputes resolution. His scientific output includes also a clear synthesis of collective labour law in Poland presented in the monograph Collective Labour Law in Poland (1999).

Professor Seweryński has been also dealing with numerous other issues related to labour law that have not been mentioned so far, to name a few that were the subject of some of his works: counteracting unemployment, child and youth labour, organisation of work, fundamental social rights, the relationship between politics, economy and labour law, flexibility of employment and contractualisation of labour relations.

A particular field of interest in the Professor's academic aspirations in the 80's was the issue of reforming and later of codifying individual and collective labour law. He wrote ten publications on this subject, apart from works on proposed changes in the law concerning detailed issues. He pursued the reform of the law by being a member of the Legislative Council and by participating in the works of the Committee for the Reform of the Labour Law. He chaired the works of the latter since 2003 until their end and he later presented to the Government (2006) drafts of two codes reforming respectively the individual and the collective labour law 4 .

It is impossible to present all of Professor Seweryński's achievements on a few pages. However, it is necessary to underline a series of publications presenting changes in the Polish labour law abroad as well as the Polish doctrine in this field, including in the book: Polish Labour Law and Collective Labour Relations in the Period of Transformation (1995) and Polish Labour Law from Communism to Democracy (1999). Especially the latter shows how the Polish labour law has been shaped since the $2^{\text {nd }}$ World War, its main institutions and perspectives for growth in the light of the most important events of those times. We also have to mention a series of works, mainly in English and in French, presenting labour law and industrial relations related issues in Central and Eastern Europe during the transitional phase of systemic transformation until its accession to the EU, to the Western Europe. They were accompanied by publications showing West-European countries legislation in Poland.

${ }^{4}$ More on this subject: G. Goździewicz, Profesor Michał Seweryński Przewodniczacy Komisji Kodyfikacyjnej Prawa Pracy w latach 2003-2006, a publication in the above book. 
Separate attention shall be paid to the works of Michał Seweryński in the fields beyond labour law, nevertheless connected with his social and professional involvement as well as with his beliefs. The first such a field is education and higher education. Reflections and suggestions on this subject are included namely in the publications on: remuneration in education (1981), academic criteria of higher education institutions (1994), ethical problems of the educational process (2004), Polish academic policy in the context of accession to the EU (2006) and strategic targets of higher education (2011). Professor Seweryński is strongly attached to Christian values hence his statements clearly showing their importance, namely in the publications on Christian identity in contemporary Europe (2008) and on the dignity of work in the light of the social doctrine of the Church (2011).

\section{*}

The Professor's academic work has been always connected with his 34 activity in management of academic education. He was among those who initiated the creation of the Conference of Presidents of Polish Academic Schools as a platform for dialogue and representation in matters related to science and higher education. Professor Seweryński was elected its President (1990-1996) and this confirmed his academic position and authority that he has enjoyed ever since. As the Conference's President Michał Seweryński defended the position and the role of universities. When speaking on 4 January 1996 during the audience granted by the Holy Father John Paul II to presidents of Polish universities he underlined the threat stemming from instrumental treatment of universities as enterprises providing specialists and harnessed by centres of power to achieve political and economic aims. In order to prevent this threat, according to him, higher education schools shall remain faithful to the perennial mission of universities and the reason for their existence i.e. to look for the truth and to spread it among the people.

In 2005 Professor Michał Seweryński became a member of the Polish Government where he remained until 2007 holding first the office of the Minister of Education and later of the Minister of Science and Higher Education ${ }^{5}$. In this par excellence political capacity he directed his efforts

${ }^{5}$ More on this period of Professor Seweryński's activity see J. Wojtyła, Stowo o Profesorze Michale Seweryńskim, [in:] Profesor Michał Seweryński, [in:] Sylwetki Łódzkich Uczonych ..., p. 22. 
mainly at adapting the system of research and higher education in Poland to the requirements stemming from the needs for development of the Polish economy and culture.

Voluntary activity of Professor Seweryński completes the picture of his diverse occupations. For many years (1996-2006) he was a member of the Pontifical Council for the Laity where he was appointed by the Pope John Paul II and in the years 1997-2005 he chaired the National Council of Lay Catholics, a consultative body of the Polish Episcopal Conference. From 1999 to 2005 he was the Honorary Consul of France in Łódź. Since 2011 Professor Seweryński has been the senator of the Polish Republic and has been a very active chair of the Senate Committee for Human Rights, Rule of Law and Petitions.

*

Professor Michał Seweryński has been awarded for his activity with the following distinctions Knight's and Officer's Cross of the Order of Polonia Restituta, Chevalier del'Ordre national du Mérite (France), Les Palmes Académiques (France), the Papal Cross Pro Ecclesia et Pontifice, the Honorary Distinction of the City of Łódź and the degree honoris causa of the Jean Moulin University (Lyon III) in Lyon.

*

At work and in everyday life Professor Seweryński has always had the support of his family - wife Bożenna Maria, son Piotr, daughter Justyna and grandsons: Filip, Mateusz and Bartłomiej. They have had very cordial and close relations always supporting each other in ambitious endeavours and difficult moments. But work is not all in his life. He has been known for his love for music and singing inherited from his parents but also for sports that he is still practising. Professor Seweryński is passionate about reading, hence his well-known erudition as well as about travelling - you need to be careful when calling Professor's cell phone as you never know where he might be at the moment and what might the additional cost that will be shown on your bill. 



\section{Zbigniew Hajn*}

\section{Le Professeur Michał Seweryński Cinquante années de travail passionné ${ }^{1}$}

hacun peut vivre cinquante années de travail de manière terne, tout en restant invisible. Le professeur Seweryński les a vécu avec passion, une ferme volonté d'agir et de changer les choses. Dès ses débuts, il a occupé une place bien visible, avec le temps devenue exposée, dans les domaines de son intérêt. Il a souvent mis en exergue que le mieux est ennemi du bien. Il est toujours fidele à cette devise.

*

Son parcours scientifique commence en 1965, par études doctorales à l'Université de Łódź, sous la tutelle du professeur Wacław Szubert, juste après un épisode de travail au bureau du procureur. Déjà pendant ses études le jeune étudiant Seweryński était fasciné par les cours du professeur Szubert de droit du travail et de politique sociale. Les traits éminents de l'esprit et de la personnalité de Wacław Szubert on fait de lui non seulement un maître scientifique, mais aussi un guide dans les moments importants de la vie de Michal Seweryński. Il a soutenu sa thèse de doctorat en droit du travail en 1969, reçu son agrégation en 1977. Le titre de professeur lui a été conféré en 1987.

Le professeur Seweryński est lié à l'Université de Łódź dès le début de sa carrière scientifique. Il montait en grade dans ses fonctions académiques : adjoint du doyen de la faculté de Droit et Administration (19811984), doyen de cette même faculté (1984-1987) ; ensuite recteur adjoint (1987-1990) et, à deux reprises, recteur de cette Université (1990-1996). En 1993 le professeur Seweryński a créé le Département de Droit collectif

* Docteur es Sciences, professeur extraordinaire de l’Université de Łódź, directeur du Département du Droit de Travail européen et collectif, juge à la Cour suprême.

1 Traduit en français par Krzysztof Brzeziński. 
du Travail à la faculté de Droit et d'Administration, tout en initiant, avec un groupe de collaborateurs, les recherches et l'enseignement dans ce secteur du droit du travail nouvellement formé. Ensuite, en 1994, dans le contexte de l'adhésion de la Pologne aux Communautés européennes, percevant la nécessité de former les futurs cadres et de mener des recherches dans le domaine du droit des Communautés européennes, il a organisé la chaire de Droit européen - Chaire Jean Monet. Trois établissements la formaient: Droit économique européen, Droit social européen et Droit institutionnel européen. Une telle structure de la Chaire a permis de lancer des recherches de grande envergure, tandis que les séminaires scientifiques mensuels, animés avec une stricte régularité par le professeur Seweryński, ont assurés aux participants, étudiants et doctorants, la possibilité d'approfondir et de discuter les différents thèmes du droit européen ${ }^{2}$. Plus tard, la Chaire est devenue un important et dynamique centre scientifique et didactique dans ce domaine du droit, formant les chercheurs, organisant des conférences et publiant la revue "Etudes de droit européen ", dont le professeur Seweryński était rédacteur en chef. Sous sa direction, cinq chercheurs ont reçu le titre de docteur es sciences. Trois - sont devenus professeurs agrégés et un - professeur. Au cours de cette période deux chercheurs de la Chaire sont devenus juges (au Tribunal de la fonction publique de l'Union européenne et à la Cour suprême de la République de Pologne), un chercheur est devenu membre du Conseil législatif, deux ont assumés des fonctions gouvernementales (Ministère du Travail et Ministère des Affaires étrangères). En 2008, compte tenu des évolutions en personnel et les besoins scientifiques, la Chaire de Droit européen a été divisée en deux structures : jusqu'à la retraite, le professeur Seweryński a assuré la direction de la Chaire de Droit économique européen et de droit collectif du travail. Pendant toutes ses années à l'Université de Łódź, y compris la période au cours de laquelle il était ministre du Gouvernement de la République de Pologne, le Professeur a donné des cours. Actuellement il est toujours actif, comme chercheur et enseignant à l'Université de Łódź, en qualité de professeur ordinaire au Département de Droit européen et de Droit collectif du travail. Il a été, à plusieurs reprises, rapporteur de thèses de doctorat, d'agrégation ou professorales.

De 1996 à 2005, Michał Seweryński a également été professeur à l'Ecole supérieure salésienne d'économie et de gestion, coopérant avec 1’ Université de Łódź. En 1997-2013 il a assuré la fonction de directeur du Centre du dialogue social du travail auprès de l'Académie économique

${ }^{2}$ Ce domaine des activités du professeur Seweryński - M. Królikowska-Olczak, Profesor Michat Seweryński - twórca Katedry Prawa Europejskiego w Uniwersytecie Łódzkim, [w :] Profesor Michał Seweryński, [w :] Sylwetki Łódzkich Uczonych, red. Z. Hajn, Ed. Łódzkie Towarzystwo Naukowe, Łódź 2009, p. 19. 
à Katowice - centre scientifique et pédagogique réalisant des recherches et assurant l'assistance dans le domaine du dialogue social du travail.

Le professeur Seweryński participe aux travaux des sociétés scientifiques polonaises: la Société scientifique de Łódź (de 1984), le Comité des sciences juridiques de l'Académie polonaise des sciences (membre en 2002-2005) et de l'Association polonaise du Droit du travail et de la Sécurité sociale, dont il est membre depuis 1980 et a été président de 1999 à 2008.

Le professeur Seweryński est actif depuis de longues années en dehors de la Pologne. A l'étranger il anime des cours et des recherches. Ceci est possible grâce à sa très bonne maîtrise du français, de l'anglais et du russe, ainsi qu'à la connaissance de quelques autres langues. Ses contacts avec les milieux scientifiques étrangers ont commencés déjà en 1971-1972, lors de sa participation aux cours d'été en droit de travail comparé à l'Ecole internationale de Droit du travail et de la Sécurité sociale à Trieste. Les cours et les examens se tenaient en langue française, mais le Professeur a été fortement impressionné par l'Italie et par la langue italienne. Il maintien des contacts avec ce pays jusqu'aujourd'hui. En 1977 il a suivi un stage de six mois à l'Université Paris I - Sorbonne. Ce stage lui a donné l'occasion d'amplifier ses centres d'intérêt scientifiques et de nouer de précieux contacts avec les milieux universitaires français. Plus tard il a travaillé dans plusieurs universités françaises. Il a été, à plusieurs reprises, rapporteur général de différents congrès européens et mondiaux du droit du travail et de la sécurité sociale, ainsi que de droit comparé, ce qui témoigne de la position qu'il occupe dans le monde international de la science. Il a également était visiting professor des universités de Paris, Bordeaux, Nantes, Saint-Etienne, Québec, Barcelone, Genève et Tokyo, ainsi que conférencier à part entière du Séminaire international de Droit du travail et de la Sécurité sociale à Szeged et, ensuite, à Bordeaux. Il est membre actif de plusieurs sociétés scientifiques étrangères : Société de Législation comparée, sise à Paris (de 1979), Association russe du Droit du travail de Moscou (de 1993), Academia Europaea sise à Londres (de 1995), Académie internationale de Droit comparé à Paris (de 2000), Association Henri Capitant à Paris (à partir de 2004 - en qualité de président de la Section polonaise de cette Association), Société historique et littéraire polonaise à Paris (de 2008, co-président du Conseil scientifique avec Mme Hélène Carrère d'Encausse - Secrétaire perpétuelle de l'Académie Française), International Society for Labour and Social Security Law à Genève (de 1980). Le professeur Seweryński a été vice-président (2000-2003) et président (2009-2012) de cette dernière organisation, la plus importante association internationale de droit du travail et de la sécurité sociale ${ }^{3}$.

${ }^{3}$ Voir L. Florek, Dorobek zagraniczny i międzynarodowy prof. zw. dr. hab. Michała Seweryńskiego, [w :] Profesor Michał Seweryński, [w :] Sylwetki Łódzkich Uczonych..., s. 13-14. 
L'œuvre scientifique en droit du travail a occupé, et occupe toujours, une place importante dans le travail du professeur Michał Seweryński. Sa création scientifique comprend plus de 170 titres, dont 60 sont des publications en langues étrangères (anglais, français, allemand, russe et espagnol). Toutes ces œuvres ont un fil conducteur - celui d'un clair respect de l'Homme et de son travail, ainsi que d'un refus de toute forme de domination des objectifs politiques et économiques réalisés au dépend des travailleurs. Outre les valeurs morales et scientifiques, l'œuvre du Professeur se caractérise par une structure transparente et logique, un exposé claire et un langage soigné. Sa sensibilité dans ce domaine est connue dans les milieux scientifiques et parmi les étudiants.

L'œuvre de Michał Seweryński est riche et variée, se rapportant à différents domaines du droit du travail. Toutefois, certains éléments occupent une place particulière dans ses acquis. Il a consacré plusieurs publications à une des institutions fondamentales du droit du travail - la rémunération du travail. Sa monographie de cette institution (Wynagrodzenie za prace, Ed. PWN, Varsovie 1981) est toujours d'actualité dans sa couche théorique, constituant un ouvrage de premier ordre dans ce domaine. Le professeur Seweryński s'est également intéressé au droit international du travail. Il a notamment publié en 1983 un livre sur les conventions de l'OIT ratifiées par la Pologne, l'assortissant d'une riche introduction sur les mécanismes de l'OIT, ainsi que sur l'impact de ces conventions sur la législation nationale. Il a également mis en évidence l'importance, au cours de cette période, de la présence de références d'un droit du travail démocratique. Il a complété cette œuvre, publiant en 1988 (avec Ludwik Florek) un livre sur le droit international du travail - Międzynarodowe prawo pracy, qui encore aujourd'hui est un manuel de base de ce domaine du droit du travail en Pologne. Depuis les années 1980, le Professeur, faisant preuve d'une sensibilité particulière, s'occupe du problème de la participation des travailleurs à la gestion de l'établissement et de l'entreprise (constituant la majeure partie du droit du travail de l'Union européenne). Il lui a consacré plusieurs ouvrages, développant les différents concepts de ce domaine du droit du travail collectif, tout en participant au débat scientifique international, notamment propageant en Pologne les acquis internationaux et présentant à l'étranger les concepts polonais. L'acquis du Professeur est notamment illustré par le Handbook on Employee Involvement in Europe publié en 2005 et co-rédigé avec le professeur Manfred Weiss. Le professeur Seweryński s'est également dédié aux questions du dialogue social, $\mathrm{du}$ status des syndicats et des organisations patronales, ainsi qu'au problème des contrats collectifs de travail et autres conventions collectives, 
instruments fondamentaux de ce dialogue. Parmi les publications dédiées à ces sujets, il faut notamment mentionner le Collective Agreements and Individual Contracts of Employment (2003), comprenant des textes de plusieurs pays, ainsi qu'une minutieuse analyse comparative rédigée par le Professeur lui-même. Il a également été rapporteur général au 17e Congrès international de l'Académie de droit comparé « Representation of Employees in Collective Bargaining within the Firm » (publication de 2007). Le Professeur a consacré cinq ouvrages au thème de la solution des conflits collectifs de travail. Son acquis comprend aussi une synthèse avisée du système de droit collectif du travail en Pologne, présentée dans la monographie Collective Labour Law in Poland (1999).

Le Professeur s'est également penché sur de nombreux thèmes du droit du travail, qui ne sont pas énumérés ici, et notamment - pour ne citer que les sujets faisant l'objet de plusieurs publications - la lutte contre le chômage; le travail des enfants et des mineurs; l'organisation du travail; les droits sociaux fondamentaux; les relations du droit du travail avec la politique et l'économie ; la flexibilité de l'emploi et la contractualisation des rapports de travail.

Depuis les années 1980, le Professeur a porté un intérêt particulier à une matière occupant une place unique dans ses recherches scientifiques. Il s'agit de la question de la réforme, et - par la suite, de la nouvelle codification du droit du travail individuel et collectif. Il a dédié à ce thème une dizaine de publications, sans compter les ouvrages relatifs aux propositions de modification du droit dans des secteurs détaillés. Il a également exprimé sa volonté de réformer le droit en assurant, pendant de longues années, la fonction de membre du Conseil législatif, ainsi qu'au sein de nombreuses commissions de réforme du droit du travail. Depuis 2003 il a été président de la dernière de ces commissions - la Commission de Codification du droit du Travail, jusqu'à la conclusion de ses travaux et la présentation au gouvernement, en 2006, des projets de deux codes réformant le droit du travail individuel et collectif ${ }^{4}$.

Il est impossible de présenter dans une esquisse la totalité de l'œuvre du professeur Seweryński. Il convient, toutefois, de mentionner une série de publications présentant à l'étranger les transformations du droit du travail en Pologne, ainsi que les acquis de la doctrine nationale de ce droit, et notamment les livres Polish Labour Law and Collective Labour Relations in the Period of Transformation (1995) et Polish Labour Law from Communism to Democracy (1999). Ce dernier illustre les changements du droit du travail en Pologne après la Seconde Guerre Mondiale, ses institutions

${ }^{4}$ Pour approfondir: G. Goździewicz, Profesor Michat Seweryński Przewodniczacy Komisji Kodyfikacyjnej Prawa Pracy w latach 2003-2006, texte publié dans le présent ouvrage. 
fondamentales et les perspectives d'évolution dans le contexte des plus importants événements de cette période. Il faut également citer une série de publications, en anglais et français, présentant en Europe occidentale les problèmes du droit du travail et des rapports de travail en Europe centrale et orientale, notamment au cours de la période de transition des systèmes politiques jusqu'à l'adhésion à l'Union européenne. Cette série est assortie de publications, parues en Pologne, sur le droit des Etats occidentaux.

$$
*
$$

Un chapitre spécifique doit être consacré aux acquis de Michał Seweryński en dehors du droit du travail, mais liés à son engagement socio-professionnel et à ses convictions. Ces premiers sont relatifs à l'éducation et l'instruction supérieure. Les concepts et les propositions du Professeur sont notamment présentés dans ses textes sur le système de rémunération dans la science (1981), les critères de qualification universitaire des écoles supérieures (1994), les problèmes éthiques du processus pédagogique (2004), de la politique scientifique nationale dans le contexte de l'adhésion à l'Union européenne (2006), ainsi que les objectifs stratégiques de l'instruction supérieure (2011). En outre, le Professeur exprime son attachement aux valeurs chrétiennes, mettant en exergue l'importance qu'il leur attribue, notamment par ses ouvrages sur l'identité chrétienne en Europe contemporaine (2008) et la dignité du travail de l'être humain à la lumière de la doctrine sociale de l'Eglise (2011).

$$
*
$$

L'activité scientifique du Professeur a toujours été accompagnée par sa forte présence dans le domaine de la gestion de la science. Il a été un des partisans de la création de la Conférence des recteurs des écoles supérieures en Pologne, comme plate-forme de dialogue et de représentation de la science et de l'enseignement supérieur. Il a été président de cette Conférence en 1990-1996, ce qui est une reconnaissance de sa position en tant que chercheur et de son autorité dans le milieu universitaire. Assurant cette fonction, Michał Seweryński a défendu la position et le rôle des universités. Prenant parole lors de l'audience accordée le 4 janvier 1996 par le Saint Père Jean-Paul II aux recteurs polonais, le Professeur a souligné les dangers résultant d'un traitement instrumental des universités, comme entreprises fournissant des experts et exploitées par les pouvoirs pour la mise en œuvre d'objectifs politiques et économiques. Il a notam- 
ment indiqué, que pour éviter cette menace il était indispensable de rester fidèle à la mission séculaire de l'université et à sa raison d'être, soit la recherche de la vérité et sa divulgation auprès des hommes.

En 2005, le professeur Michał Seweryński a été nommé membre du Gouvernement de la République de Pologne. Jusqu'en 2007 il a occupé la fonction de ministre de l'éducation et ensuite ministre de la science et de l'instruction supérieure ${ }^{5}$. Assumant ces postes, par excellence politiques, il s'est concentré sur l'adaptation du système de la recherche scientifique et de l'instruction supérieure en Pologne aux besoins du développement de l'économie et de la culture polonaises.

L'image des activités diverses et variées du professeur Seweryński est complétée par son activité sociale. Notamment, pendant de nombreuses années (1996-2006) il a été membre du Conseil pontifical pour les laïcs, nommé par le pape Jean-Paul II. En 1997-2005 il a été président du Conseil national des catholiques laïcs, organe consultatif de la Conférence de l'Episcopat de Pologne. De 1999 à 2005 il a été consul honoraire de France à Łódź. Depuis 2011 le Professeur est sénateur de la République de Pologne et assume la fonction de président de la Commission du Sénat pour les droits de l'Homme, la légalité et les pétitions.

$*$

Le professeur a été honoré de la Croix de Chevalier et de la Croix d'Officier dans l'Ordre de Renaissance de la Pologne, de Chevalier dans l'Ordre national du Mérite (France), les Palmes Académiques (France), la Croix pontificale Pro Ecclesia et Pontifice, la Médaille d'honneur de la ville de Łódź, ainsi que le titre de docteur honoris causa de l'Université Jean Moulin (Lyon III) à Lyon.

*

Le Professeur est soutenu dans sa vie professionnelle et privée par une famille heureuse: son épouse Bożenna Maria, son fils Piotr, sa fille Justyna, et ses petits-fils Filip, Mateusz et Bartłomiej. Tous les membres

${ }^{5}$ A lire sur ce domaine des activités du professeur Seweryński-dans J. Wojtyła, Słowo o Profesorze Michale Seweryńskim, [w:] Profesor Michał Seweryński, [w:] Sylwetki Łódzkich Uczonych..., p. 22. 
de la famille sont unis par des liens très cordiaux et chaleureux, se soutenant réciproquement dans la réalisation de projets ambitieux et dans tous les moments difficiles. La vie du Professeur n'est pas faite uniquement de travail. Tous connaissent sa passion pour la musique et le chant, héritée, selon ses propos, de ses parents. Mais aussi pour le sport, qu'il pratique jusqu'aujourd'hui. La lecture est une autre des passions du Professeur, liées aussi bien au passe-temps qu'au travail. C'est à elle qu'il doit sa renommée d'érudite. Il adore le tourisme. En conséquence, toute personne composant le numéro de son portable, doit prévoir la possibilité de payer une surtaxe pour communication à longue distance. 